\title{
Paralegal Students' and Paralegal Instructors' Perceptions of Synchronous and Asynchronous Online Paralegal Course Effectiveness: A Comparative Study
}

\author{
Kristine Farmer ${ }^{1}$, Jeff Allen ${ }^{1}$, Malak Khader ${ }^{1}$, Tara Zimmerman ${ }^{1}$, Peter \\ Johnstone $^{1}$ \\ 1University of North Texas, United State. \\ skfarmer@outlook.com; jeff.allen@unt.edu; taradz37@gmail.com; malakkhader@my.unt.edu; peter.johnstone@unt.edu \\ *Corresponding Author: jeff.allen@unt.edu |Phone Number: +19404539020
}

\begin{abstract}
To improve online learning pedagogy within the field of paralegal education, this study investigated how paralegal students and paralegal instructors perceived the effectiveness of synchronous and asynchronous online paralegal courses. This study intended to inform paralegal instructors and course developers how to better design, deliver, and evaluate effective online course instruction in the field of paralegal studies. Survey results were analyzed using independent samples t-test and correlational analysis, and indicated that overall, paralegal students and paralegal instructors positively perceived synchronous and asynchronous online paralegal courses. Paralegal instructors reported statistically significant higher perceptions than paralegal students: (1) of instructional design and course content in synchronous online paralegal courses; and (2) of technical assistance, communication, and course content in asynchronous online paralegal courses. Instructors also reported higher perceptions of the effectiveness of universal design, online instructional design, and course content in synchronous online paralegal courses than in asynchronous online paralegal courses. Paralegal students reported higher perceptions of asynchronous online paralegal course effectiveness regarding universal design than paralegal instructors. No statistically significant differences existed between paralegal students' perceptions of the effectiveness of synchronous and asynchronous online paralegal courses. A strong, negative relationship existed between paralegal students' age and their perceptions of effective synchronous paralegal courses, which were statistically and practically significant. Lastly, this study provided practical applicability and opportunities for future research.
\end{abstract}

Keywords: paralegal studies; synchronous; asynchronous; online learning; remote learning; distance learning; course effectiveness;

\section{Introduction}

This study replicates the 2007 study by Tung entitled, "Perceptions of Students and Instructors of Online and Web-enhanced Course Effectiveness in Community Colleges," for his doctoral dissertation at the University of Kansas (2007). This study employs the same survey instruments used by Tung (2007) but adapted to paralegal students and paralegal instructors in the United States across all types of institutions and degrees. The purpose of this study is to measure the perceptions of paralegal students and paralegal instructors toward the effectiveness of synchronous and asynchronous online paralegal courses.

\subsection{Need for the Study}

Paralegals play a significant role in the delivery of legal services in common law jurisdictions, including the United States, England, Wales, and Australia. While the paralegal profession has a long, respected history in England and Wales, tracing its beginnings to the 1800s (Johnstone \& Flood, 1982), it is still a young profession by comparison in the United States, formally created in the late 1960s (McCabe, 2007). The American Bar Association (ABA) has identified over 1000 institutions that offer paralegal education programs (ABA, 2017). offering certificate programs as well as associate's, bachelor's, and master's degrees (AAfPE, 2017). These programs are offered by public and private institutions and vary in length and format, from exclusively face-to-face courses to fully online programs and hybrid combinations of both.

Growth of online enrollment across colleges and universities in the United States now surpasses traditional, face-to-face enrollment (Rich \& Dereshiwsky, 2011). As a result, distance learning and online 
education is becoming a standard of practice in higher education (Bernard et al., 2009). In order to improve online learning pedagogy within the field of paralegal education, studies of perceptions of course effectiveness by paralegal students and paralegal instructors are needed to inform instructors and course developers on ways to increase the effectiveness of web-based learning in these courses.

\subsection{Theoretical Framework}

This study relies on constructivist theory as its primary theoretical framework, with the model of Community of Inquiry as a supporting framework. The Community of Inquiry (CoI) framework provides a collaborative constructivist model that deems online courses as successful when students engage both in a collaborative and individual "search for meaning and understanding" (Akyol, Garrison, \& Ozden, 2009, p. 66; Garrison, Anderson, \& Archer, 2000). Together, instructors and students form a community of online learning encompassing three elements: cognitive presence, social presence, and teaching presence (see Fig. 1) (Garrison, Anderson \& Archer, 2000, pp. 88-89). This community of learning also includes categories and indicators that explain each presence and suggest qualitative coding (see Fig. 2) (Garrison, Anderson \& Archer, 2000, pp. 88-89).

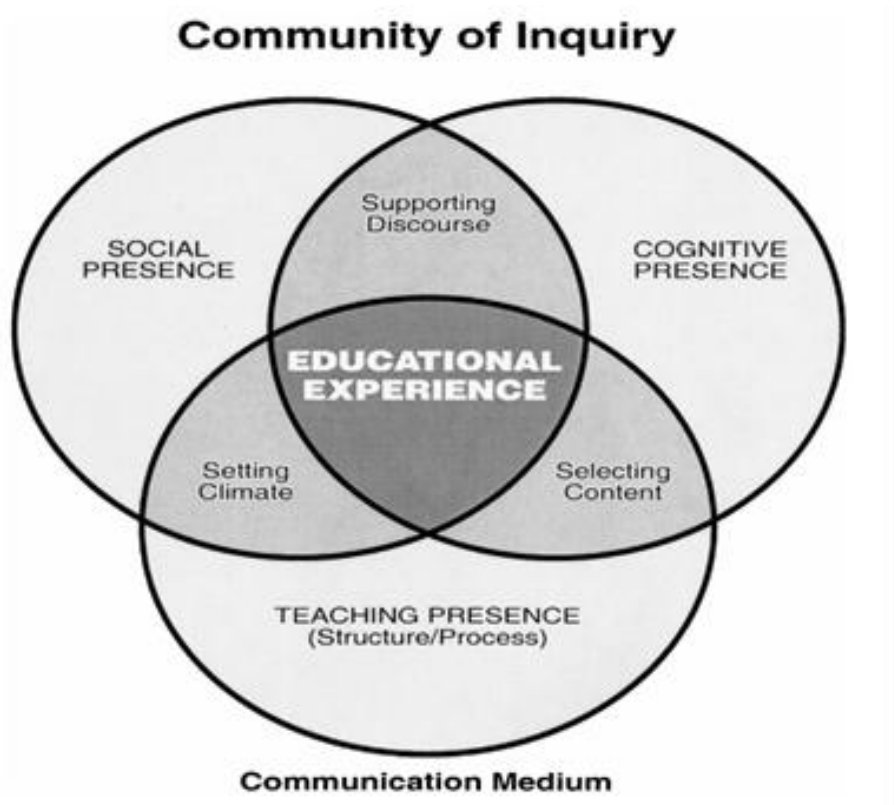

Figure 1. Community of Inquiry Framework ${ }^{1}$

\begin{tabular}{|c|c|c|}
\hline ELEMENTS & CATEGORIES & $\begin{array}{l}\text { INDICATORS } \\
\text { (examples only) }\end{array}$ \\
\hline Social Presence & $\begin{array}{l}\text { Open Communication } \\
\text { Group Cohesion } \\
\text { Affective Expression }\end{array}$ & $\begin{array}{l}\text { Risk-free expression } \\
\text { Encourage collaboration } \\
\text { Emoticons }\end{array}$ \\
\hline Cognitive Presence & $\begin{array}{l}\text { Triggering Event } \\
\text { Exploration } \\
\text { Integration } \\
\text { Resolution }\end{array}$ & $\begin{array}{l}\text { Sense of puzzlement } \\
\text { Information exchange } \\
\text { Connecting ideas } \\
\text { Apply new ideas }\end{array}$ \\
\hline Teaching Presence & $\begin{array}{l}\text { Design \& Organization } \\
\text { Facilitating Discourse } \\
\text { Direct Instruction }\end{array}$ & $\begin{array}{l}\text { Setting curriculum \& } \\
\text { methods } \\
\text { Sharing personal meaning } \\
\text { Focusing discussion }\end{array}$ \\
\hline
\end{tabular}

Figure 2. Community of Inquiry Elements, Categories, and Indicators ${ }^{2}$

The CoI framework dovetails with paralegal online learning and online course effectiveness. Cognitive presence is key to critical thinking (Tung, 2007). According to the American Association for Paralegal Educations "Paralegal Core Competencies" (2013), critical thinking is the highest core competency in a paralegal education curriculum. Logical argument and higher levels of thinking are components of 
cognitive development and constructivism (Leahey \& Harris, 2000), and as such, form a foundation for paralegal education and online paralegal courses.

\subsection{Purpose of the Study}

Several factors support the purpose of this study. First, online enrollment in the United States is growing, with one-third of college students enrolled in at least one online course (Allen \& Seaman, 2014). Second, there is a lack of current empirical studies related to online learning pedagogy within the field of paralegal education in the United States. Third, the ABA's guidelines state that paralegal programs must require students to take nine semester credits of legal specialty paralegal courses through traditional classroom instruction in order to become or maintain ABA-approval. Taken together, this study fills the literature gap related to the effectiveness of online paralegal education.

Thus, this study measures the perceptions of paralegal students and paralegal instructors toward the effectiveness of synchronous and asynchronous online paralegal courses. Research Questions

1. Are there significant differences between paralegal students' and instructors' perceptions of synchronous online paralegal course effectiveness?

2. Are there significant differences between paralegal students' and paralegal instructors' perceptions of asynchronous online paralegal course effectiveness?

3. Are there significant relationships between paralegal students' perceptions of synchronous online paralegal course effectiveness subscales and students' demographic characteristics?

\section{Literature Review}

Few studies have examined online paralegal courses in the United States. A literature search reveals one empirical, peer-reviewed article that assesses student outcomes from online paralegal courses (Taggart \& Bodle, 2003), an informational journal article related to computer assisted instruction in paralegal education (Johnson \& Taggart, 1996), and one primer on distance education in paralegal studies (Myers, 2002). Because the research topic for this study and the informational articles are unrelated, and because of the small sample size $(n=41)$ for the Taggart and Bodle (2003) study, the results are unlikely to apply to all online paralegal courses in the United States, leaving a paucity of empirical studies on the effectiveness of online paralegal education. To the best of our knowledge, no national study of paralegal students' and instructors' perceptions of online paralegal course effectiveness has been conducted.

\subsection{Perceptions of Online Course Effectiveness}

Perceptions can significantly influence decisions and behaviors (Otter et al., 2013; Reimman \& Bechara, 2010). Perceptions of quality of instruction, instructor, and other students' motivations to take online courses can have a positive impact on a student's decision to enroll in online courses (Mayes, 2001; Otter et al., 2013). For this study, perceptions of course effectiveness are measured related to paralegal students' and paralegal instructors' gender, age, native language, educational level, technology skills, and synchronous or asynchronous online course experience.

\subsection{Student Perceptions of Online Course Effectiveness}

Researchers have found that students perceive online courses as beneficial, though not all of those benefits are knowledge related (Yang \& Cornelius, 2004). Indeed, students' positive perceptions of the quality of online courses include flexibility, cost-effectiveness, and ease of internet connection to be positive online course experiences (e.g., Astani, Ready, \& Duplaga, 2010; Liu, Gomez, Khan, \& Yen, 2007; Steiner \& Hyman, 2010; Tanner, Noser, \& Tottaro, 2009; Wilkes, Simon, \& Brooks, 2006; Yang \& Cornelius, 2004), while negative perceptions include an instructor's lack of technical support, tedious and uninteresting instructional methods, and poorly designed course content (Yang \& Cornelius, 2004). Strikingly, a high positive correlation exists between student perceived overall course value and assignment practicality $(r=$ $.808)$ and course materials' usefulness and relevance $(r=.787)$ in student perceptions of effective online teaching. This effectiveness includes valuing instructors who develop online courses with thoughtful organization and careful structure, ensuring that content and materials are practical, relevant, and presented articulately (Jones, 2012).

\subsection{Age and Gender}

Age has been found to have no significant effect on academic performance in online courses across disciplines. In a study of business law students, Dutcher, et al. (2015) found that gender and age, among other demographics, had no significant impact on student satisfaction of online courses. Two years earlier, 
Otter, et al. (2013) reported that $95 \%$ of students in online courses across disciplines were between the ages of 18 and 34, split equally between male and female students. Nevertheless, the study found a significant difference between male and female students' positive perceptions of the effectiveness of online course content, where the mean of female students was statistically higher $(M=4.2, S D=.61)$ than the mean of the male group $(M=3.7, S D=.72)$ (Seok, DaCosta, Kinsell, \& Tung, 2010).

\subsection{Technology Skills and Online Course Experience}

Students deficient in the requisite technological skills for web-based learning may fear enrolling in online courses. Indeed, a student's previous technological experience affects their attitudes surrounding technology overall (Martins \& Kellermanns, 2004; Stoel \& Lee, 2003). Technological difficulties rather than content focus can adversely affect student satisfaction in online courses (Harrell, 2008; Lowerison et al., 2006; Thurmond, Wambach, Connors \& Frey, 2010; Vodanovich \& Piotrowski, 2000).

In a study of business faculty and students, those who had no previous online course experience felt the technology skills needed for the course improved the educational experience (Lowerison, Sclater, Schmid, \& Abrami, 2006; Tanner, Noser, \& Totaro, 2009). Finally, graduate students across disciplines felt their experience with technology influenced their perceptions of how useful the technology was for online learning (Song, et al., 2004).

\subsection{Instructor Perceptions of Online Course Effectiveness}

Faculty perceptions of online course effectiveness include instructional design and instructor presence (Lockee, Burton, \& Potter, 2010; Sheridan \& Kelly, 2010), as well as technological self-efficacy, years of teaching online, and number of online courses taught (Cherry \& Flora, 2017; Tanner, Noser, \& Totaro, 2009). Similar to students', positive perceptions of the quality of online courses include flexibility, user interface, navigation, course management, technical support, universal design, and course content (Bailey \& Card, 2009; Inman, Kerwin, \& Mayes, 1999; Otter et al. 2013; Seok, Kinsell, DaCosta, \& Tung, 2010; Wilkes, Simon, \& Brooks, 2006).

\subsection{Age and Gender}

One study investigating student perceptions of online instruction revealed no significant difference between courses taught by male instructors $\left(x^{-}=4.29\right)$ versus female instructors $\left(x^{-}=4.26\right)$ (Shook, Greer \& Campbell, 2013). Faculty perceptions of online course effectiveness were not significantly affected by faculty age, $r(213)$ $=-.013, P=.854$ (Cherry \& Flora, 2017). A study of community college faculty revealed no statistically significant difference in faculty perceptions of course effectiveness across faculty gender (Tung, 2007).

Seok et al. (2010) found that female instructors had statistically significant higher perceptions of online course effectiveness compared to male instructors. Instructors who were younger and possessed less teaching experience were more likely to embrace online learning than their older, more experienced colleagues (Myers, Bennett, Brown, \& Henderson, 2004).

\subsection{Technology Skills and Online Course Experience}

Online course instructors underscored the importance of developing appropriate technical competencies and leveraging them to effectively deliver course content (Bailey \& Card, 2009). The relationship of faculty perceptions of course effectiveness to years of teaching online courses was found to be a statistically significant relationship. The perception of course effectiveness increased both with the number of years teaching online courses $r(214)=.209, p=.002$, and with the increased number of online courses taught, $r(213)$ $=.282, p<.001$ (Cherry \& Flora, 2017).

Faculty with no experience teaching online courses believed the quality was inferior to traditional faceto-face courses (Inman, Kerwin, \& Mayes, 1999). Similar to their student counterparts, faculty with little to no experience in the delivery of online courses perceived this lack of experience to be a barrier to teaching online courses compared to those instructors who had more online course development and teaching experience (Lloyd, Byrne, \& McCoy, 2012). As observed by Seok, et al. (2010), having advanced technology skills and experience likely affect instructors' perceptions of online course effectiveness.

\section{Methods}

This study measures how paralegal students and paralegal instructors perceive the effectiveness of synchronous and asynchronous online paralegal courses. This study uses a nonexperimental quantitative research design with independent samples $t$-tests and correlational analysis of data obtained through two self-reported survey instruments from paralegal students and paralegal instructors. Using independent 
samples $t$-test is appropriate "when two or more means are being compared" (Salkind, 2008, p. 378), such as the means of paralegal students' perceptions and paralegal instructors' perceptions. Correlational analysis measures the relationship between variables, and specifically, "how the value of one variable changes when the value of another variable changes" (Salkind, 2008, p. 74). For this study, correlational analysis is used to measure the relationships between paralegal students' perceptions and their demographic variables.

This study uses a multicourse and multiversity strategy, which provides statistical benefits (Robinson \& Hullinger, 2008). The researchers draw conclusions about two populations using samples drawn from those populations using quantitative research methodologies (Gall, Borg, \& Gall, 1996), appropriate for this investigation. Additionally, descriptive statistics of the demographic information of the sample populations are presented.

Eleven dependent variables are used to ascertain the perceptions of paralegal students and paralegal instructors of online course effectiveness using the following subscales: flexibility, user interface, navigation, getting started, technical assistance, course management (instructor), course management (student), universal design, communication, instructional design, and content. Further, this study assesses the independent variables of gender, age, native language, educational level, technology skills, and course experience with synchronous and asynchronous online paralegal courses to determine whether these variables are significant factors in dependent variables of the participants' perceptions of online course effectiveness.

Challenges to experimental validity have been considered and attempts to control these are made in the research design. Plausible threats to internal validity included nonresponse bias, volunteer bias, and instrumentation bias (McMillan, 2008). Nonresponse and volunteer bias may occur in this study because data collection is conducted through a web-based survey in which participants could avoid responding (Alreck \& Settle, 2004). Thus, in order to control for these related threats to internal validity, we maximized the response rate through data collection procedures including repeated contact attempts through reminder emails scheduled at effective time intervals. This study attempts to avoid instrumentation bias by using an instrument with demonstrated evidence of validity and score reliability in the literature (Popham, 2000).

Two threats to external validity are of primary concern. First, selecting participants almost exclusively from the United States' American Association for Paralegal Education (AAfPE) membership population may limit generalizability to the broader population of paralegal instructors. Due to the popularity of AAfPE membership among paralegal educators (AAfPE, 2017), this is not anticipated to be a major threat to external validity. Nevertheless, this is noted as a delimitation of the study. Second, with the volunteer nature of the sample, the study captures and evaluates sample characteristics to ensure that they match the defined population.

\subsection{Sampling}

The sampling approach for this study is a convenience sampling. With over 400 members, the AAfPE is the only association of its kind in the United States. AAfPE members consist of paralegal educators from fouryear institutions offering baccalaureate degrees in paralegal studies as well as instructors from two-year colleges that offer associate's degrees and certificates (AAfPE, 2017). This researcher utilized the AAfPE private listserv as well as its LinkedIn group to gather participants. Paralegal instructors were informed of the study through discussion posts in AAfPE's private listserv and on the AAfPE LinkedIn group's webpage. To increase the response rate, we emailed paralegal educators individual invitations to participate in this study. Further, we asked these paralegal instructors to invite their students to participate in the study.

Following sample size tables developed by Krejcie and Morgan (1970), the sample size representative of the defined population of paralegal instructors $(X \approx 570)$ who are teaching, or have previously taught, synchronous or asynchronous online paralegal courses is 226 . Similarly, the sample size representative of the defined population of paralegal students $(X \approx 3,200)$ who are currently enrolled in, or have previously been enrolled in, synchronous or asynchronous online paralegal courses was 341. In an effort to meet the representative sample, paralegal instructors who were members of the American Association for Paralegal Education were invited to participate in the study.

A minimum of 128 total participants, or 64 paralegal instructors and paralegal students, was recommended through the G-Power analysis to provide enough statistical power to support statistical significance. Using GPower 3.1.0, a statistical power analysis was conducted to increase the probability that the tests would find statistically significant differences (Faul, Erdfelder, Lang, \& Buchner, 2007). The a error of probability was set to .05 with a power (1- $\beta$ error probability) of .8 , and the effect size was set at .25 . According to Cohen (1988), .30-.50 effect size defines a moderate to medium effect. The projected power was set at .80, indicating an $80 \%$ or greater chance of finding statistically significant results when, in fact, there is 
one. These parameters were used to calculate the sample size of 128, or 64 for each group, which is considered acceptable.

\subsection{Instrumentation}

This study uses survey research as its selected method and employs two validated survey questionnaires used in the Tung (2007) study to collect and measure data. Each survey questionnaire contains two sections: (1) personal data and (2) perceptions of course effectiveness.

We asked all participants for personal data including their gender, year of birth, current state of residence, native language, paralegal education level, general education level, and technology skills. In addition, we asked paralegal students the number of synchronous online paralegal courses and asynchronous online paralegal courses they had completed. Similarly, we asked paralegal instructors the number of synchronous online paralegal courses and asynchronous online paralegal courses they had taught.

The perception of course effectiveness section consists of 99 questions using a five-point Likert-type scale response. A Likert-type scale consists of a series of declarative statements. Five levels are used to record the responses: " 1 = strongly disagree," "2 = disagree," "3 = neutral," "4 = agree," and " 5 = strongly agree." Each statement is positively worded, and participants are asked to indicate to what extent they agree or disagree. An open-ended question is included at the end of the survey to collect additional comments.

The survey questionnaires focus on participants' perception in the following areas of online course effectiveness: flexibility (6 items), user interface ( 9 items), navigation (6 items), getting started (6 items), technical assistance (4 items), course management (10 items, 7 items), universal design (7 items), communication (8 items), instructional design (22 items), and content (14 items).

Similar to Tung's (2007) study, the measurements of perceptions of course effectiveness are adapted from a validated instrument. Two subject matter experts, professors at a research university affiliated with a research and development unit within their own institutions, validated the survey instruments. Cronbach's coefficient alphas were used to compute internal consistency estimates of reliability for each subscale of the instrument. Tung (2007) noted that the alpha coefficient ranges in value from 0 to 1 , which describes the reliability of factors extracted from dichotomous and/or multi-point formatted questionnaires or scales. The higher the score, the more reliable the generated scale (Santos, 1999). Nunnaly (1978) indicated 0.7 to be an acceptable reliability coefficient. With an internal consistency estimate of reliability, individuals were administered a measure with multiple parts on a single occasion (Green \& Salkind, 2005). No items needed to be reverse-scaled because all survey questions were presented in positively worded statements. All items shared the same metric since the response scale for all items is $1=$ "strongly disagree" to $5=$ "strongly agree." Reliability and validity remained consistent compared to Tung's (2007) original instrument. All subscales in this study had alpha levels greater than 0.7 , indicating acceptable reliability.

\subsection{Data Collection}

Data were collected in two phases: 1) paralegal instructor; and 2) paralegal students. In the first phase, paralegal instructors were invited to participate via the AAfPE members' only listserv, the AAfPE LinkedIn Group, and by individual email (Appendix B). The survey data were collected using UNT's Qualtrics Survey Software. An anonymous link to the survey was sent to participants to access the online consent form. The survey link was available for two months, from February 22, 2018 until April 22, 2018.

In the second phase of data collection, paralegal students were asked to participate in the study by their instructors via email or a survey link in their online classroom (Appendix B). The survey was administered in the same way as the paralegal instructors survey and was available during exactly the same time period. Each participant was able to take the survey only once. After the participant completed the survey, the data were stored in Qualtrics to be reviewed and analyzed.

\subsection{Data Analysis}

The data were analyzed to determine the answers to each of the research questions using SPSS 25.0 (Statistical Package for Social Sciences) for statistical analyses. An alpha level of .05 was used for all research questions to determine statistical significance, while a moderate to medium effect size of $.30-.50$ (Cohen, 1988), was used to determine practical significance.

Several statistical assumptions were made before employing the independent samples $t$-test, a statistical technique to determine differences between two groups, and the Pearson Correlation Coefficient, a statistical technique to explore the strength of the relationship between two variables (Field, 2009). To control statistical errors, Levene's Test for Equality of Variances tested whether the variance of scores of the two groups, respectively, was the same. The outcome of the Levene's Test determined which $t$-values should be 
used. Before performing the Pearson Correlation Coefficient, scatterplots were generated to check for violations of the assumptions of linearity and homoscedasticity, and to better understand the nature of the relationship between the variables.

For Research Questions 1 and 2, independent samples t-tests were conducted to evaluate whether the paralegal instructors' perceptions of online paralegal course effectiveness subscales (flexibility, user interface, navigation, getting started, technical assistance, course management, universal design, communication, instructional design, and content) were significantly different across the dependent variables of gender, age, native language, paralegal education level, education level, technology skills, number of synchronous and asynchronous online paralegal courses taught or taken. Because each of the variables constructed contained multiple items, composite means were computed for each of the variables' constructs. The Pearson Correlation Coefficient analysis was used to test Research Question 3. Because each of the variables' constructs contained multiple items, composite means were computed for each of the variables' constructs. The demographic data were analyzed using descriptive statistics in SPSS.

\section{Results}

\subsection{Sample Size}

All participants have taken or taught at least one online paralegal course. The resulting sample size totaled 156, with 89 valid responses from paralegal students and 67 valid responses from paralegal instructors, exceeding the required minimum sample size of 128 .

\subsection{Descriptive Statistics}

Paralegal Students' Descriptive Demographics and Perceptions. Of the valid survey completions, $78 \%$ of the paralegal student respondents were female and $92 \%$ were native English speakers. Respondents' year of birth determined respondents' generational cohort. Across these cohorts, 6\% were born between 1946 and 1964; 15\% were born between 1965 and 1976; 58\% were born between 1977 and 1995; and 22\% were born after 1996. In response to highest educational level, $6 \%$ had master's degrees, $29 \%$ had bachelor's degrees, $22 \%$ had associate's degrees, $37 \%$ had taken some college courses, and $6 \%$ had a high school diploma or GED. For technology skills, $69 \%$ had advanced technology skills, $30 \%$ had intermediate technology skills, and $1 \%$ had beginner technology skills. The average number of synchronous online paralegal courses taken was $1(S D=3)$. The average number of asynchronous online paralegal courses taken were $4(S D=3)$. Table 1 lists the descriptive statistics results of the paralegal students' perceptions subscales.

Table 1. Paralegal Students' Perceptions of Online Paralegal Course Effectiveness by Subscales

\begin{tabular}{llcc}
\hline & N & Mean & Std. Deviation \\
\hline Flexibility & 89 & 4.44 & .48 \\
User Interface & 89 & 4.19 & .55 \\
Navigation & 89 & 4.19 & .62 \\
Getting Started & 89 & 4.23 & .62 \\
Technical Assistance & 89 & 3.86 & .75 \\
Course Management (Instructor) & 89 & 4.22 & .55 \\
Course Management (Student) & 89 & 4.39 & .50 \\
Universal Design & 89 & 4.08 & .59 \\
Communication & 89 & 4.32 & .55 \\
Online Instructional Design & 89 & 4.08 & .53 \\
Content & 89 & 4.28 & .50 \\
\hline
\end{tabular}

Paralegal Instructors' Descriptive Demographics and Perceptions. Of the valid survey completions, $73 \%$ of the paralegal instructor respondents were female and 100\% were native English speakers. Across the generational cohorts, 56\% were born between 1946 and 1964; 38\% were born between 1965 and 1976; and 6\% were born between 1977 and 1995. Regarding highest educational level, 80\% had doctoral or professional terminal degrees (e.g., juris doctor), 18\% had master's degrees, and 2\% had bachelor's degrees. For technology skills, $79 \%$ had advanced technology skills and $21 \%$ had intermediate technology skills. The average number of synchronous online paralegal courses taught was $4(S D=16)$, and the average number of asynchronous online paralegal courses taught was $19(S D=25)$. Table 2 lists the descriptive statistics results of the paralegal instructors' perceptions subscales. 
Table 2. Paralegal Instructors' Perceptions of Online Paralegal Course Effectiveness by Subscales

\begin{tabular}{llcc}
\hline & $\mathrm{N}$ & Mean & Std. Deviation \\
\hline Flexibility & 67 & 4.46 & .46 \\
User Interface & 67 & 4.25 & .43 \\
Navigation & 67 & 4.09 & .45 \\
Getting Started & 67 & 4.13 & .58 \\
Technical Assistance & 67 & 4.30 & .85 \\
Course Management (Instructor) & 67 & 4.27 & .46 \\
Course Management (Student) & 67 & 4.46 & .41 \\
Universal Design & 67 & 3.95 & .52 \\
Communication & 67 & 4.61 & .43 \\
Online Instructional Design & 67 & 4.24 & .45 \\
Content & 67 & 4.64 & .44 \\
\hline
\end{tabular}

The analyses validated the instrumentation, data, and methodology used to answer the study's research questions. Methods included reliability and validity analysis, independent samples $t$-test, and correlation analysis.

\subsection{Data Analysis}

Research Question 1: Are there significant differences between paralegal students' perceptions and paralegal instructors' perceptions of synchronous online paralegal course effectiveness?

Independent samples $t$-tests compare paralegal students' perceptions and paralegal instructors' perceptions of synchronous online paralegal courses subscales of flexibility, user interface, navigation, getting started, technical assistance, course management (instructor), course management (student), universal design, communication, online instructional design, and content. No significant differences in scores are found for paralegal students' perceptions and paralegal instructors' perceptions for the following subscales, and the magnitude of the differences in means for each is minimal: flexibility, user interface, navigation, getting started, technical assistance, course management (instructor), course management (student), universal design, and communication.

However, statistically significant differences for the subscale of online instructional design appear between paralegal students' perceptions $(M=4.03, S D=.50$; and paralegal instructors' perceptions $(M=4.41, S D=$ $.26) ;(t(29)=2.41, p<.05)$. The magnitude of the difference in the means (mean difference $=.39,95 \% \mathrm{CI}: .06$ to .72$)$ represents a medium-size effect $(r=0.41)$.

Statistically significant differences occur between paralegal students' perceptions $(M=4.19, S D=.46)$ and paralegal instructors' perceptions $(M=4.84, S D=.17)$ for the subscale of content $(t(29)=5.63, p<.001)$. The magnitude of the difference in the means (mean difference $=.65,95 \% \mathrm{CI}: .41$ to .89 ) represents a largesize effect $(r=0.74)$.

Therefore, paralegal instructors tend to report higher perceptions of effective synchronous online course instructional design and course content than paralegal students.

This study adds to the body of knowledge in the context of positive perceptions of the quality of online courses that include flexibility, user interface, navigation, course management, technical support, and universal design (Bailey \& Card, 2009; Inman, Kerwin, \& Mayes, 1999; Otter et al., 2013; Seok, Kinsell, DaCosta, \& Tung, 2010; Wilkes, Simon, \& Brooks, 2006), and extends the research to the field of paralegal studies. This study also adds to the body of knowledge in the context of instructor and student perceptions of instructional design (Lockee, Burton, \& Potter, 2010; Song, Singleton, Hill, \& Koh, 2004), reflecting that instructional design is crucial for effective online learning. And, this study further supports the research of Tung (2007) as the results find that paralegal instructors' perceptions are higher than paralegal students' regarding effective synchronous online course instructional design and content.

Finally, these findings support the research of Ward, Peters, and Shelley (2010), who suggested to an instructor who was reluctant "to employ online learning" that paralegal students' perceive "it is possible to achieve levels of effectiveness in an online instructional format similar to those that are realized in face-toface delivery" (p. 16).

Table 3. Results of t-tests and Descriptive Statistics for Paralegal Students' and Paralegal Instructors' Perceptions of Synchronous Online Course Effectiveness Subscales

\begin{tabular}{|c|c|c|c|c|c|c|c|c|c|}
\hline \multirow[t]{3}{*}{ Outcome } & \multicolumn{6}{|c|}{ Group } & \multirow{3}{*}{$\begin{array}{l}\text { 95\% CI for Mean } \\
\text { Difference }\end{array}$} & \multirow[b]{3}{*}{$t$} & \multirow[b]{3}{*}{ df } \\
\hline & \multicolumn{3}{|c|}{ Paralegal Students } & \multicolumn{3}{|c|}{ Paralegal Instructors } & & & \\
\hline & $M$ & $S D$ & $N$ & $M$ & $S D$ & $N$ & & & \\
\hline Flexibility & 4.32 & .38 & 20 & 4.42 & .34 & 11 & $-.17, .39$ & .78 & 29 \\
\hline User Interface & 4.28 & .56 & 20 & 4.18 & .35 & 11 & $-.42, .24$ & -.56 & $28.49^{a}$ \\
\hline Navigation & 4.30 & .65 & 20 & 4.08 & .32 & 11 & $-.58, .13$ & -1.28 & 29 \\
\hline Getting Started & 4.28 & .65 & 20 & 4.20 & .50 & 11 & $-.52, .35$ & -.41 & $25.72^{\mathrm{a}}$ \\
\hline
\end{tabular}




\begin{tabular}{|c|c|c|c|c|c|c|c|c|c|}
\hline $\begin{array}{l}\text { Technical } \\
\text { Assistance }\end{array}$ & 3.88 & .78 & 20 & 4.07 & .78 & 11 & $-.40, .79$ & .66 & 29 \\
\hline Course & & & & & & & & & \\
\hline $\begin{array}{l}\text { Management } \\
\text { (instructor) }\end{array}$ & 4.14 & .50 & 20 & 4.25 & .38 & 11 & $-.24, .48$ & .69 & 29 \\
\hline Course & & & & & & & & & \\
\hline $\begin{array}{l}\text { Management } \\
\text { (student) }\end{array}$ & 4.40 & .53 & 20 & 4.38 & .39 & 11 & $-.40, .35$ & -.13 & 29 \\
\hline Universal Design & 4.04 & .58 & 20 & 4.27 & .44 & 11 & $-.18, .64$ & 1.15 & 29 \\
\hline Communication & 4.35 & .53 & 20 & 4.61 & .46 & 11 & $-.13, .65$ & 1.38 & 29 \\
\hline $\begin{array}{l}\text { Online Instructional } \\
\text { Design }\end{array}$ & 4.03 & .50 & 20 & 4.41 & .26 & 11 & $.06, .72$ & $2.41^{*}$ & 29 \\
\hline Content & 4.19 & .46 & 20 & 4.84 & .17 & 11 & $.41, .89$ & $5.63^{* *}$ & $26.58^{a}$ \\
\hline
\end{tabular}

Note: ${ }^{a}$ Degrees of freedom are adjusted to account for not meeting the homogeneity of variance assumption.

* indicates significance at the $\mathrm{p}<.05$ level

** indicates significance at the $\mathrm{p}<.001$ level

Research Question 2: Are there significant differences between paralegal students' perceptions and paralegal instructors' perceptions of asynchronous online paralegal course effectiveness?

Independent samples $t$-tests compare paralegal students' perceptions and paralegal instructors' perceptions of asynchronous online paralegal course subscales of flexibility, user interface, navigation, getting started, technical assistance, course management (instructor), course management (student), universal design, communication, online instructional design, and content. No statistically significant differences appear in scores of paralegal students' perceptions and paralegal instructors' perceptions of the following subscales, and the magnitude of the differences in means for each is minimal: flexibility, user interface, navigation, getting started, course management (instructor), course management (student), and online instructional design (see Table 4).

However, there are statistically significant differences for the subscale of technical assistance between paralegal students' perceptions $(M=3.86, S D=.75)$ and paralegal instructors' perceptions $(M=4.31, S D=$ $.84) ;(t(122)=3.21, p<.05)$. The magnitude of the difference in the means (mean difference $=.46,95 \% \mathrm{CI}$ : .18 to .74$)$ represents a small-size effect $(r=0.28)$.

Statistically significant differences also appear between paralegal students' perceptions $(M=4.09, S D=$ $.60)$ and paralegal instructors' perceptions $(M=3.88, S D=.52)$ of the subscale of universal design $(t(122)=$ $321, p<.05$ ). The magnitude of the difference in the means (mean difference $=-.21,95 \%$ CI: -.41 to -.00 ) represents a small-size effect $(r=0.18)$.

Also, there are statistically significant differences between paralegal students' perceptions $(M=$ $4.31, S D=.56)$ and paralegal instructors' perceptions $(M=4.61, S D=.43)$ of the subscale of communication $(t(122)=3.30, p<.05)$. The magnitude of the difference in the means (mean difference $=.30,95 \% \mathrm{CI}: .12$ to $.48)$ represents a small-size effect $(r=0.29)$.

Statistically significant differences occur between paralegal students' perceptions $(M=4.31, S D=.50)$ and paralegal instructors' perceptions $(M=4.60, S D=.46)$ of the subscale of content $(t(122)=3.23, p<.05)$. The magnitude of the difference in the means (mean difference $=.28,95 \%$ CI: .11 to .46 ) represents a smallsize effect $(r=0.28)$. Therefore, paralegal students report higher perceptions of effective asynchronous online universal design than paralegal instructors. Conversely, paralegal instructors report higher perceptions of effective asynchronous online course communication and course content than paralegal students.

These findings support studies conducted by Bailey and Card (2009) and Inman, Kerwin, \& Mayes (1999) on how instructors perceived online courses and instructor and student attitudes towards distance learning. The research of Tanner, Noser, and Totaro (2009), found some differences in perception about online learning between students and instructors. The results also suggest that in some instances, paralegal students perceive effective asynchronous online course universal design more highly. Paralegal students also have lower perceptions of effective asynchronous course communications and content, consistent with the research performed by Wilkes, Simon, and Brooks (2006) and by Yang and Cornelius (2004). These results also support the research of Seok, DaCosta, Kinsell, and Tung (2010), who found that instructors had statistically higher perceptions of the effectiveness of online courses than did students. 
Table 4. Results of t-tests and Descriptive Statistics for Paralegal Students' and Paralegal Instructors' Perceptions of Asynchronous Online Course Effectiveness Subscales

\begin{tabular}{|c|c|c|c|c|c|c|c|c|c|}
\hline \multirow[t]{3}{*}{ Outcome } & \multicolumn{6}{|c|}{ Group } & \multirow{3}{*}{$\begin{array}{l}\text { 95\% CI for Mean } \\
\text { Difference }\end{array}$} & \multirow[b]{3}{*}{$t$} & \multirow[b]{3}{*}{$\mathrm{df}$} \\
\hline & \multicolumn{3}{|c|}{ Paralegal Students } & \multicolumn{3}{|c|}{ Paralegal Instructors } & & & \\
\hline & $M$ & $S D$ & $N$ & $M$ & $S D$ & $N$ & & & \\
\hline Flexibility & 4.48 & .50 & 69 & 4.46 & .49 & 55 & $-.19, .15$ & -.20 & 122 \\
\hline User Interface & 4.16 & .55 & 69 & 4.25 & .44 & 55 & $-.89, .27$ & 1.00 & 122 \\
\hline Navigation & 4.15 & .61 & 69 & 4.08 & .47 & 55 & $-.26, .12$ & -.72 & $121.93^{a}$ \\
\hline Getting Started & 4.22 & .62 & 69 & 4.14 & .57 & 55 & $-.29, .14$ & -.67 & 122 \\
\hline $\begin{array}{l}\text { Technical } \\
\text { Assistance } \\
\text { Course }\end{array}$ & 3.86 & .75 & 69 & 4.31 & .84 & 55 & $.18, .74$ & $3.21^{*}$ & 122 \\
\hline $\begin{array}{l}\text { Management } \\
\text { (instructor) } \\
\text { Course }\end{array}$ & 4.24 & .56 & 69 & 4.28 & .48 & 55 & $-.15, .22$ & .38 & $121.26^{\mathrm{a}}$ \\
\hline $\begin{array}{l}\text { Management } \\
\text { (student) }\end{array}$ & 4.39 & .49 & 69 & 4.46 & .41 & 55 & $-.86, .24$ & .93 & $121.68^{a}$ \\
\hline Universal Design & 4.09 & .60 & 69 & 3.88 & .52 & 55 & $-.41,-.00$ & $-2.01^{*}$ & 122 \\
\hline $\begin{array}{l}\text { Communication } \\
\text { Online }\end{array}$ & 4.31 & .56 & 69 & 4.61 & .43 & 55 & $.12, .48$ & $3.30^{*}$ & 122 \\
\hline $\begin{array}{l}\text { Instructional } \\
\text { Design }\end{array}$ & 4.10 & .54 & 69 & 4.19 & .48 & 55 & $.09, .28$ & 1.00 & 122 \\
\hline Content & 4.31 & .50 & 69 & 4.60 & .46 & 55 & $.11, .46$ & $3.23^{*}$ & 122 \\
\hline
\end{tabular}

Note: a Degrees of freedom are adjusted to account for not meeting the homogeneity of variance assumption.

* indicates significance at the $p<.05$ level

Research Question 3: Are there significant relationships between paralegal students' perceptions of synchronous online paralegal course effectiveness subscales and students' demographic characteristics?

The Pearson Correlation Coefficient measures the relationship between paralegal students' perceptions of synchronous online paralegal course effectiveness and the paralegal students' demographic characteristics of gender, age, highest education level, technology skills, and the number of synchronous courses taken (see Table 5). Preliminary analyses were performed to ensure no violation of the assumption of normality, linearity, and homoscedasticity. The results indicated that there were no statistically significant relationships between paralegal students' gender, education level, technology skills, or the number of synchronous courses taken and their perceptions of synchronous online paralegal course effectiveness related to the subscales of flexibility, navigation, getting started, technical assistance, course management (instructor), course management (student), and communication. There were strong, negative correlations between paralegal students' age and the paralegal students' perceptions of synchronous online paralegal course effectiveness for the subscales of user interface $(r=-.50, n=20, p<.05$ level (2-tailed)), navigation $(r=$ -.48, $n=20, p<.05$ level (2-tailed)), universal design $(r=-.52, n=20, p<.05$ (2-tailed)), and online instructional design $(r=-.62, n=20, p<.001$ level (2-tailed)).

Practical significance can be determined by the effect size of the correlation, or the coefficient of determination, as represented by $r^{2}$. The coefficient of determination varies from 0 to 1.00 and indicates that the proportion of variance in the scores can be predicted from the relationship between variables. In this study, the coefficient of determination is .25 for user interface, .23 for navigation, .27 for universal design, and .38 for online instructional design, which means that $25 \%$ of the variation in the mean of user interface, $23 \%$ for navigation, $27 \%$ for universal design, and $38 \%$ for online instructional design, respectively, can be predicted from paralegal students' age.

For the behavioral sciences, correlation coefficients of .10, .30, and .50 irrespective of positive or negative are, by convention, interpreted as small, medium, and large coefficients, respectively (Green \& Salkind, 2005).

The results indicate strong, negative correlations between paralegal students' age and how they perceive synchronous online paralegal course effectiveness for the subscales of user interface, universal design, and online instructional design, all of which are practically significant. Students' perceptions of the effectiveness of user interface, universal design, and online instructional design decrease with each generational cohort. In other words, Baby Boomers' perceptions of course effectiveness for these subscales are higher than that of Gen X, whose perceptions are higher than that of Millennials', whose perceptions, in turn, are higher than that of Gen Z. 
Table 5. Pearson Correlation Coefficient (r) for Paralegal Students' Perceptions of Synchronous Online Paralegal Course Effectiveness by Subscales

\begin{tabular}{|c|c|c|c|c|c|}
\hline & Gender & Age & Education Level & Technology Skills & $\begin{array}{c}\text { Number of } \\
\text { Synchronous Courses } \\
\text { Taken }\end{array}$ \\
\hline Flexibility & .27 & -.37 & -.04 & .29 & .16 \\
\hline User Interface & .17 & $-.50^{*}$ & .16 & .31 & -.09 \\
\hline Navigation & .05 & $-.48^{*}$ & .10 & .16 & -.06 \\
\hline Getting Started & -.19 & -.20 & -.34 & .11 & .05 \\
\hline Technical Assistance & .00 & -.41 & -.21 & .02 & -.18 \\
\hline Course Management (Instructor) & .16 & -.41 & -.23 & .13 & .14 \\
\hline Course Management (Student) & .33 & -.30 & .09 & .12 & .17 \\
\hline Universal Design & .24 & $-.52^{*}$ & -.11 & .14 & -.14 \\
\hline Communication & .31 & -.24 & .17 & .44 & -.02 \\
\hline Online Instructional Design & .42 & $-.62^{* *}$ & -.16 & .12 & .21 \\
\hline Content & .15 & -.42 & -.17 & .27 & .14 \\
\hline
\end{tabular}

*. Correlation is significant at the 0.05 level (two-tailed).

**. Correlation is significant at the 0.01 level (two-tailed).

\section{Discussion}

A driving premise for this study is the dearth of empirical studies within the field of paralegal studies, as well as its exclusion within the broader scope of online and distance learning education literature. These results correspond with previous research literature (Bailey \& Card, 2009; Inman, Kerwin, \& Mayes, 1999; Harrell, 2008; Jones, 2012; Lowerison, Sclater, Schmid, \& Abrami, 2006; Sheridan \& Kelly, 2010; Thurmond, Wambach, Connors \& Frey, 2010). The results also support previous research involving student and instructor perceptions of online course effectiveness performed by Astani, Ready, and Duplaga (2010), Bailey and Card (2009), Cherry and Flora (2017), Dutcher, Epps, and Cleaveland (2015), Horspool and Lange (2012), Otter, et al. (2013), and Seok, Kinsell, DaCosta, and Tung (2010), Tanner, Noser, and Totaro (2009), Ward, Peters, and Shelley (2010), and Wilkes, Simon, and Brooks (2006).

The results of this study refute previous research performed by Colorado and Eberle (2010) and refute, in part, the research by Tung (2007) and Cherry and Flora (2017), in which both studies found no statistically significant differences between both instructors' age and students' age, respectively, and course effectiveness.

Several limitations to this study affect the generalizability of the findings. The response rates may have depended on the researcher's ability to identify, contact, and obtain responses from paralegal instructors and paralegal students. The inability to reach every potential respondent contributes to the small sample size. The opinions of barriers perceived by participants may have limited the respondent's willingness, honesty, comfort level, and stress at the time they answered the questionnaire. Because the study employs selfreporting questionnaires, the data may be limited by biases resulting from their use. Self-reporting instruments measuring both dependent and independent variables often raise the issue of validity, most notably the response bias of participants (Razavi, 2001). Similarly, respondents may not accurately perceive, recall, and report their communication behaviors in the survey instruments. Because random selection and assignment are not used, external validity may be affected. The results also may be limited by the variation of each participant's definition of each item in the Likert scale, or the lack of granularity in those scales.

Although this study cannot be generalized to the greater population of all paralegal students, paralegal instructors, and all synchronous and asynchronous online paralegal courses, several practical applications can be drawn from the results of the study.

There are no statistically significant differences between paralegal instructors' and students' perceptions of the effectiveness of their synchronous and asynchronous online courses as that perception relates to flexibility, user interface, navigation, getting started, course management (instructor), and course management (student). Paralegal instructors perceive synchronous online paralegal courses to be more effective than asynchronous online paralegal courses regarding universal design, online instructional design, and course content. This study provides evidence that the paralegal profession should embrace advances in technology and eliminate any program-level requirements for traditional face-to-face paralegal courses by allowing synchronous online courses to serve as valid and acceptable alternatives to traditional paralegal courses. This will expand paralegal programs, potentially meeting the needs of smaller, more rural communities, and improve the delivery of quality legal services. This will also serve a growing, diverse student population with different educational goals, social skills, learning styles, self-discipline, and time or geographic constraints.

Paralegal instructors and instructional designers should understand the differences found in this study between paralegal student perceptions and paralegal instructor perceptions related to technical assistance, 
instructional design, communication, and course content - those areas in which instructors' perceptions are higher than those of students. Improved course effectiveness may mean an embedded technical assistance guide in each course instead of a single point of technical assistance available to all online students for all courses or greater consideration of overall course design. As online instructors likely realize, differences exist between learning in the traditional classroom and learning in the online environment. To that end, online instructors should apply instructional design techniques that facilitate participation, interaction, and engagement to promote higher student perceptions of online course effectiveness. Course design should include student-to-student, student-to-instructor, and student-to-content participation, interaction, and engagement.

Paralegal instructors should recognize that the online classroom mimics the kind of virtual or remote teams often found in law firms, corporations, and other employers of paralegals. The online classroom provides paralegal instructors a prime opportunity to give students a sense of how virtual or remote teams operate in the law firm or corporate law department environments, preparing them to communicate, receive assignments, and collaborate in these types of teams.

Paralegal students want more effective communication, rather than just more communication. Timely and constructive feedback influences how students perceive effectiveness of online courses. Practical suggestions for improving online courses include providing more substantive feedback to all students after grading each content module and assignment. The paralegal instructor should consider incorporating synchronous aspects of online communication within the asynchronous classroom, such as live blogging or maintaining synchronous online office hours available to students, depending on students' needs and demands while balancing instructor availability. Asynchronous online courses can lack the immediacy of traditional courses, but by utilizing online chats or other synchronous means of communications, the paralegal instructor can satisfy the students' desire for immediate feedback. Paralegal instructors can improve how students perceive the effectiveness of online courses by using a myriad of instructional strategies and feedback loops.

Substantive, meaningful, and timely course content directly influences how paralegal students perceive online course effectiveness. Course content should consist of current, relevant, and rich materials consistently updated to reflect paralegal students' needs and to embrace evolving learning technologies. Paralegal instructors should consider augmenting textbooks and course materials with personal stories and current events available through online videos and blogs to improve students' perceptions of course effectiveness.

This study finds a strong negative relationship between paralegal students' age and their perceptions of effective synchronous online course instructional design, universal design, navigation, and user interface. In other words, synchronous online paralegal courses are not being designed to meet the needs of younger students such as the Millennial and Generation $\mathrm{Z}$ cohorts. Instead, they are being designed targeting older students, Generation X and Baby Boomers, likely because current paralegal instructors belong predominantly to these cohorts. In this study, $94 \%$ of paralegal instructors fall within these two generational cohorts. The online environment provides instructors with the ability to leverage the Millennial and Generation Z's pervasive use of technology as a meaningful way to better engage them.

This study indicates that instructional design, user interface, navigation, and universal design of the courses need improvement. Paralegal instructors should design synchronous and asynchronous courses with focus on the end user-Millennial and the Gen Z students. This could mean employing social media, using current events as examples to underscore course content, or using both synchronous and asynchronous features within learning management systems, such as wikis, blogs, journals, instant messenger, YouTube video links, or media galleries. This could also include using collaborative teaching methods in which students learn from each other through peer assessments or group e-portfolios of substantive coursework.

\subsection{Recommendations for Future Research}

Several areas of additional research are warranted considering the results of this study and the questions left unanswered. Future research should explore the broader topics of assessing satisfaction and success of both synchronous and asynchronous online paralegal course environments and its intersection with paralegal students' and paralegal instructors' demographic characteristics.

1. There is a need to examine the roles technology and instructor innovation play in online paralegal courses, especially through the lens of student success, satisfaction, and performance. It should also address how student innovativeness may influence student success, satisfaction, and performance.

2. Future studies into online paralegal education should explore the effects of students' critical thinking skills, knowledge construction, time management, motivation, commitment, problem-solving abilities, 
learning autonomy, and student expectations of course effectiveness and efficiency as they relate to the quality and effectiveness of the online learning environment.

3. Future research should also investigate student performance in the online classroom as well as student perceptions of learning in both the synchronous and asynchronous environments. Any research undertaking the assessment of performance and perceptions of learning should go beyond simply measuring the final course grade or online course evaluations but should instead investigate performance across varying types of assignments and assess learning at different times throughout the course. Future studies should examine differences in online learning outcomes of paralegal courses between the generational cohorts of Baby Boomers, Generation X, Generation Y (Millennials), and Generation Z, especially as related to the same generational cohorts of paralegal instructors.

4. Future research should compare and assess the online paralegal course offerings in other countries of common law, such as the ILEX program in the United Kingdom, to the paralegal programs in the United States, including online course effectiveness, student and instructor satisfaction, student success, and student learning.

5. Future studies should examine the role of teaching presence, social presence, and cognitive presence in the online paralegal classroom using the CoI survey instrument (Akyol \& Garrison, 2008) to predict learning processes and learning outcomes from a paralegal studies program-wide perspective.

6. To improve the validity of future results, researchers should modify the study to require a larger sample size by group as well as consider using a source of participants other than LinkedIn groups, including paper surveys and/or in-person data collection events. Increasing the sample size requirement with support through additional recruitment options and time for data collection would provide an opportunity for researchers to better understand the true effects in the population and reduce response bias.

7. Future studies should be conducted using qualitative research methods to gain a deeper understanding of paralegal students' and instructors' perceptions of online learning.

8. Future studies should include the use of longitudinal research design to examine paralegal students' perceptions of synchronous and asynchronous course effectiveness,-enabling the researcher to measure any changes over time regarding perceived differences and relationships conducted in this study.

\subsection{Summary}

A driving premise for this study was the dearth of empirical research within the field of paralegal studies and its exclusion within the broader scope of online and distance learning education literature. To improve online learning pedagogy within the field of paralegal education, instructors and course developers need studies of perceptions of course effectiveness by paralegal instructors and paralegal students to understand how to increase the effectiveness of web-based learning in online paralegal courses. The study intends to improve online learning pedagogy within the field of paralegal education, and to fill the literature gap related to the effectiveness of online paralegal education.

\section{References}

Akyol, Z., \& Garrison, D. R. (2008). The development of a community of inquiry over time in an online course: Understanding the progression and integration of social, cognitive and teaching presence. Journal of Asynchronous Learning Networks, 12, 3-22. Retrieved from https:// files.eric.ed.gov/fulltext/EJ837483.pdf

Akyol, Z., Garrison, D. R., \& Ozden, M. Y. (2009). Online and blended communities of inquiry: Exploring the developmental and perceptional differences. The International Review of Research in Open and Distributed Learning, 10(6), 65-83. Retrieved

from http://www.irrodl.org/index.php/irrodl/article/view/765/1436

Allen, I. E., \& Seaman, J. (2014). Grade change: Tracking online education in the United States. Babson Park, MA: Babson Survey Research Group and Quahog Research Group, LLC. Retrieved from https://www.utc.edu/learn/pdfs/online/sloanc-report-2014.pdf

Alreck, P. L., \& Settle, R. B. (2004). The Survey Research Handbook (3rd ed.) New York, NY: McGraw-Hill Irwin.

American Association for Paralegal Education (2013, Oct.). AAfPE core competencies for paralegal programs. Retrieved https://cdn.ymaws.com/www.aafpe.org/resource/resmgr/Docs/AAfPECoreCompetencies.pdf

American Bar Association, Standing Committee on Paralegals. https://www.americanbar.org/groups/paralegals.html 
American Bar Association, Standing Committee on Paralegals (2013, September). Guidelines for the approval of paralegal education programs. Retrieved from https:/ / www.americanbar.org/content/dam/aba/administrative/paralegals/ls_prlgs_2013_pa ralegal_guidelines.authcheckdam.pdf

Astani, M., Ready, K. J., \& Duplaga, E. A. (2010). Online course experience matters: Investigating students' perceptions of online learning. Issues in Information Systems, 11(2), 14-21. Retrieved from http:/ / iacis.org/iis/2010/14-21_LV2010_1526.pdf

Bailey, C. J., \& Card, K. A. (2009). Effective pedagogical practices for online teaching: Perception of experienced instructors. The Internet and Higher Education, 12, 152-155. doi: 10.1016/j.iheduc.2009.08.002

Bernard, R., Abrami, P., Borokhovski, E., Wade, C., Tamim , R., Surkes, M., \& Bethel, E. (2009). A metaanalysis of three types of interaction treatments in distance education. Review of Educational Research, 79, 1243-1289. doi: 10.3102/0034654309333844

Cherry, S. J., \& Flora, B. H. (2017). Radiography faculty engaged in online education: Perceptions of effectiveness, satisfaction, and technological self-efficacy. Radiologic Technology, 88(3), 249-262. http:/ / www.radiologictechnology.org/

Cohen, J. (1988). Statistical power analysis for the behavioral sciences (2nd ed.). New York: Taylor \& Francis Group.

Colorado, J. T., \& Eberle, J. (2010). Student demographics and success in online learning environments. Emporia State Research Studies, 46(1), 4-10. Retrieved from https:/ / esirc.emporia.edu/bitstream/handle/123456789/380/205.2.pdf?sequence=1

Dutcher, C. W., Epps, K. K., \& Cleaveland, M. C. (2015). Comparing business law in online and face to face formats: A difference in student learning perception. Academy of Educational Leadership Journal, 19, 123134. http://www.abacademies.org/journals/academy-of-educational-leadership-journal-home.html

Faul, F., Erdfelder, E., Lang, A.-G., \& Buchner, A. (2007). G*Power 3: A flexible statistical power analysis program for the social, behavioral, and biomedical sciences. Behavior Research Methods, 39, 175-191. Retrieved from http://www.gpower.hhu.de/fileadmin/redaktion/Fakultaeten/MathematischNaturwissenschaftliche_Fakultaet/Psychologie/AAP/gpower/GPower3-BRM-Paper.pdf

Field, A. (2009). Discovery statistics using SPSS. (3rd ed.). Thousand Oaks, CA: Sage Publications, Inc.

Gall M., Borg, W., \& Gall, J. (1996). Educational research: An introduction (6th ed.). White Plains, NY: Longman Press.

Garrison, D. R., Anderson, T., \& Archer, W. (2001). Critical thinking, cognitive presence, and computer conferencing in distance education. American Journal of distance education, 15(1), 7-23. Retrieved from http:/ /cde.athabascau.ca/coi_site/documents/Garrison_Anderson_Archer_CogPres_Final.pdf

Green, S. B., \& Salkind, N. J. (2005). Using SPSS for Windows and Macintosh: Internal consistency estimates of reliability. Upper Saddle River, NJ: Pearson Prentice Hall.

Harrell, I. L. (2008). Increasing the Success of Online Students. Inquiry, 13(1), 36-44. Retrieved from http:/ / files.eric.ed.gov/fulltext/EJ833911.pdf

Horspool, A., \& Lange, C. (2012). Applying the scholarship of teaching and learning: student perceptions, behaviours and success online and face-to-face. Assessment \& Evaluation in Higher Education, 37, 73-88. doi: 10.1080/02602938.2010.496532

Inman, E., Kerwin, M., \& Mayes, L. (1999). Instructor and student attitudes toward distance learning. Community College Journal of Research E Practice, 23, 581-591. doi:10.1080/106689299264594

Institute of Legal Executives (ILEX). https:/ / www.cilexcareers.org.uk/

Johnson, J. \& Taggart, G. (1996). Computer assisted instruction in paralegal education: Does it help? Journal of Paralegal Education and Practice, 12, 1-21.

Johnstone, Q. \& Flood, J. (1982). Paralegals in English and American law offices. Windsor YB Access to Justice $2,152$.

Jones, S. J. (2012). Reading between the lines of online course evaluations: Identifiable actions that improve student perceptions of teaching effectiveness and course value. Journal of Asynchronous Learning Networks, 16(1), 49-58. doi:http://dx.doi.org/10.24059/olj.v16i1.227

Krejcie, R. V., \& Morgan, D. W. (1970). Determining sample size for research activities. Educational and psychological measurement, 30, 607-610. http://journals.sagepub.com/home/epm

Liu, S., Gomez, J., Khan, B., \& Yen, C. J. (2007). Toward a learner-oriented community college online course dropout framework. International Journal on ELearning, 6(4), 519-542. https://www.learntechlib.org/j/IJEL/

Lloyd, S. A., Byrne, M. M., \& McCoy, T. S. (2012). Faculty-perceived barriers of online education. Journal of online learning and teaching, 8(1), 1-12. Retrieved from http://jolt.merlot.org/vol8no1/1loyd_0312.pdf 
Lockee, B., Burton, J., \& Potter, K. (2010, March). Organizational perspectives on quality in distance learning. In D. Gibson \& B. Dodge (Eds.), Proceedings of SITE 2010 - Society for Information Technology \& Teacher Education International Conference (pp. 659-664). San Diego, CA: Association for the Advancement of Computing in Education (AACE). https://www.learntechlib.org/p/33419/

Lowerison, G., Sclater, J., Schmid, R. F., \& Abrami, P. C. (2006). Student perceived effectiveness of computer technology use in post-secondary classrooms. Computers $\mathcal{E}$ Education, 47(4), 465489. doi:10.1016/j.compedu.2004.10.014

https://pdfs.semanticscholar.org/fc9c/13f0187d3967217aa82cc96c188427e29ec9.pdf

Martins, L. L., \& Kellermanns, F. W. (2004). A model of business school students' acceptance of a web-based course management system. Academy of Management Learning \& Education,3(1), 7-26. doi: 10.5465/AMLE.2004.12436815

Mayes, J. T. (2001). Quality in an e-University. Assessment \& Evaluation in Higher Education, 26, 465-473. doi:10.1080/02602930120082032

McCabe, S. (2007). A brief history of the paralegal profession. Michigan Bar Journal, 86(7), 18-21. Retrieved from https:// www.michbar.org/file/barjournal/article/documents/pdf4article1177.pdf

McMillan, J. H. (2008). Educational Research: Fundamentals for the customer. Boston, MA: Pearson Education, Inc.

Myers, C. B., Bennett, D., Brown, G., \& Henderson, T. (2004). Emerging online learning environments and student learning: An analysis of faculty perceptions. Educational Technology \& Society, 7(1), 78-86. Retrieved from http://www.ifets.info/journals/7_1/9.pdf

Myers, K. (2002). Distance education: A primer. Journal of Paralegal Education \& Practice, 18, 57-64.

Nunnaly, J. (1978). Psychometric theory. New York: McGraw-Hill.

Otter, R. R., Seipel, S., Graeff, T., Alexander, B., Boraiko, C., Gray, J., Petersen, K., \& Sadler, K. (2013). Comparing student and faculty perceptions of online and traditional courses. The Internet and Higher Education, 19, 27-35. doi:10.1016/j.iheduc.2013.08.001

Popham, W. J. (2000). Modern educational measurement: Practical guidelines for educational leaders. Boston, MA: Allyn \& Bacon.

Rich, A. J., \& Dereshiwsky, M. I. (2011). Assessing the comparative effectiveness of teaching undergraduate intermediate accounting in the online classroom format. Journal of College Teaching and Learning, 8(9), 19. https://www.cluteinstitute.com/ojs/index.php/TLC/

Robinson, C., \& Hullinger, H. (2008). New benchmarks in higher education: Student engagement in online learning. The Journal of Education for Business, 84(2), 101-109. Retrieved from http://anitacrawley.net/Resources/Articles/New\%20Benchmarks\%20in\%20Higher\%20Education.pd $\mathrm{f}$

Salkind, N. J. (2008). Statistics for people who think they hate statistics. Los Angeles, CA: Sage Publications.

Santos, J. (1999, April). Cronbach's Alpha: A tool for assessing the reliability of scales. Journal of Extension, 37, 2. Retrieved from https://www.joe.org/joe/1999april/tt3.php

Seok, S., DaCosta, B., Kinsell, C., \& Tung, C. K. (2010). Comparison of instructors' and students' perceptions of the effectiveness of online courses. Quarterly Review of Distance Education, 11(1), 25. Retrieved from http://online.nuc.edu/ctl_en/wp-content/uploads/2015/08/Online-education-effectiviness.pdf

Sheridan, K., \& Kelly, M. A. (2010). The indicators of instructor presence that are important to students in online courses. Journal of Online Learning and Teaching,6(4), 767-779. Retrieved from http://jolt.merlot.org/vol6no4/sheridan_1210.pdf

Shook, B. L., Greer, M. J., \& Campbell, S. (2013). Student perceptions of online instruction. International Journal of Arts \& Sciences, 6(4), 337. Retrieved from https://s3.amazonaws.com/academia.edu.documents/34496977/Ophoff.pdf?AWSAccessKeyId=AKI AIWOWYYGZ2Y53UL3A\&Expires=1508119686\&Signature=J11J8VO0xardd\%2FwH35pGj14UeBg\%3D \&response-content-

disposition=inline\%3B\%20filename\%3DStudent_Perceptions_of_Online_Learning.pdf

Song, L., Singleton, E. S., Hill, J. R., \& Koh, M. H. (2004). Improving online learning: Student perceptions of useful and challenging characteristics. The Internet and Higher Education, 7, 5970. doi:10.1016/j.iheduc.2003.11.003

Steiner, S. D., \& Hyman, M. R. (2010). Improving the student experience: Allowing students enrolled in a required course to select online or face-to-face instruction. Marketing Education Review, 20, 29-34. doi:10.2753/MER1052-8008200105

Stoel, L., \& Hye Lee, K. (2003). Modeling the effect of experience on student acceptance of web-based courseware. Internet Research, 13(5), 364-374. http://www.emeraldinsight.com/loi/intr

Taggart, G., \& Bodle, J. H. (2003). Example of assessment of student outcomes data from on-line paralegal courses: Lessons learned. Journal of Paralegal Education \& Practice, 19, 29-36. 
Tanner, J. R., Noser, T. C., \& Totaro, M. W. (2009). Business faculty and undergraduate students' perceptions of online learning: A comparative study. Journal of Information Systems Education, 20, 29-40. http:/ /jise.org/

Tung, C.K. (2007). Perceptions of students and instructors of online and web-enhanced course effectiveness in community colleges (Doctoral dissertation). Retrieved from ProQuest Dissertations and Theses database (Publication No. AAT 3284232).

Vodanovich, S. J. \& Piotrowski, C., \& (2000). Are the reported barriers to Internet-based instruction warranted? A synthesis of recent research. Education, 121(1), 48-53. http://www.projectinnovation.com/education.html

Ward, M. E., Peters, G., \& Shelley, K. (2010). Student and faculty perceptions of the quality of online learning experiences. The International Review of Research in Open and Distributed Learning, 11, 57-77. Retrieved from http:/ / www.irrodl.org/index.php/irrodl/article/view/867/1610?

Wilkes, R. B., Simon, J. C., \& Brooks, L. D. (2006). A comparison of faculty and undergraduate students' perceptions of online courses and degree programs. Journal of Information Systems Education, 17, 131140. http://jise.org/

Yang, Y., \& Cornelius, L. F. (2004). Students' perceptions towards the quality of online education: A qualitative approach. Association for Educational Communications and Technology, 27, 861-877. Retrieved from http:/ / files.eric.ed.gov/fulltext/ED485012.pdf 